\title{
PENGARUH LAMA FERMENTASI OLEH Bacillus subtilis TERHADAP KARAKTERISTIK SERE KEDELE
}

\author{
Effect of Fermentation Time by Bacillus subtilis on The Characteristic of Sere Kedele
}

\author{
Sri Madiarti Sipayung1) , I Wayan Rai Widarta ${ }^{2)}$, I Desak Putu Kartika Pratiwi ${ }^{2)}$ \\ ${ }^{1}$ Mahasiswa Program Studi Ilmu dan Teknologi Pangan, Fakultas Teknologi Pertanian, Universitas Udayana \\ ${ }^{2}$ Dosen Program Studi Ilmu dan Teknologi Pangan, Fakultas Teknologi Pertanian, Universitas Udayana \\ PS Ilmu dan Teknologi Pangan, Fakultas Teknologi Pertanian, Universitas Udayana, \\ Kampus Bukit Jimbaran, Badung-Bali
}

\begin{abstract}
This research aims to find out the effect of soybean fermentation time by Bacillus subtilis to produce sere kedele with the best characteristics. This research used completely randomized design (CRD) with one treatment factor of the fermentation time with 5 period of fermentation time (12,18, 24, 30 and 36h). Each treatment was repeated 3 times, resulted 15 experimental units. The data were then analyzed with Analysis of Variance method and if the treatment had an effect on the variable, followed by the Duncan test. The result show that fermentation times had significant effect to moisture, ash, protein, fat, carbohydrate, crude fiber content, total acid, $\mathrm{pH}$ value, the number microbes, hedonic test for taste, scoring test for taste and overall acceptance of sere kedele. Fermented by B. subtilis for $12 \mathrm{~h}$ resulted in the best characteristic under the following criteria : $58.05 \%$ moisture content, $2.39 \%$ ash content, $15.79 \%$ protein content, $14.39 \%$ fat contetnt, $9,38 \%$ carbohydrate content, $6.1 \mathrm{pH}$ value, $0.11 \%$ total acid, $9.59 \log \mathrm{cfu} / \mathrm{g}$ the number microbes, color, flavour, texture liked, normal taste with sour taste and overall acceptance liked.
\end{abstract}

Keyword : soybean, sere kedele, Bacillus subtilis, fermentation, traditional food .

\section{PENDAHULUAN}

Sere kedele merupakan salah satu pangan tradisional yang diproduksi oleh penduduk di pesisir Tenggara Pulau Bali. Sere kedele terbuat dari kedelai sebagai bahan utama yang diolah secara tradisional melalui proses fermentasi dan penambahan bumbu sebagai cita rasa, selanjutnya digoreng atau diawetkan dengan dibentuk bulat pipih kemudian dijemur hingga kering. Bumbu yang digunakan berupa bawang merah, bawang putih, gula, garam, merica, kunyit, lengkuas, ketumbar dan cabe yang terlebih dahulu dihaluskan. Proses fermentasi berlangsung secara spontan, mikroba yang tumbuh kemungkinan berasal dari wadah, udara dan daun-daunan yang digunakan sebagai penutup (Koswara, 1997).

Sere kedele memiliki kesamaan dengan pangan tradisional hasil fermentasi kedelai di wilayah asia seperti Natto di Jepang, Chongkukjang di Korea, Thua nao di Thailand dan Kinema di India. Kesamaan pada produk fermentasi kedelai ini yaitu terdapat bakteri dominan yang membantu berlangsungnya proses fermentasi kedelai yaitu Bacillus subtilis (Tamang, 2015), bahan baku yang digunakan dan metode yang hampir sama dengan proses produksi sere kedele. Perbedaan sere kedele dengan produk kedelai fermentasi lainnya hanya pada jenis bumbu yang digunakan pada proses fermentasi.

Menurut Walianingsih (2015), proses produksi sere kedele dengan fermentasi spontan memerlukan waktu 30 jam dengan kondisi suhu ruang untuk menghasilkan produk dengan karakteristik terbaik. Widyantari (2016) melaporkan sere kedele yang beredar di pasar umum Kabupaten Gianyar memiliki kandungan nutrisi dengan kadar air berkisar antara 56,89\% - 64,65\%; kadar abu $1,56 \%$ - 2,42\%; kadar protein $14,90 \%$ - 20,93\%; kadar lemak 5,34\% 9,50\% dan kadar karbohidrat 10,81\% $12,97 \%$. Waktu proses produksi sere kedele memerlukan waktu yang cukup lama dengan lama fermentasi 1 sampai 2 hari dan hingga

\footnotetext{
*Korespondensi Penulis:

E-mail: srimadiarti@gmail.com ${ }^{1)}$
} 
saat ini proses produksi sere kedele masih dilakukan dengan cara tradisional, kedelai dimasak dengan perebusan dan fermentasi secara spontan (alami) sehingga kualitas produk yang dihasilkan tidak konsisten, keamanannya tidak terjaga dengan baik dan produksinya memerlukan waktu yang lama.

Penelitian yang dilakukan oleh Wei dkk. (2001), melaporkan bahwa karakteristik kedelai fermentasi pada natto, dipengaruhi oleh lama pemasakan, lama fermentasi dan jenis bakteri. Proses fermentasi pada produksi natto memerlukan waktu selama 18 jam menggunakan inokulum $B$. subtilis natto sebanyak $10^{6}-10^{7} \mathrm{cfu} / \mathrm{g}$ dengan suhu fermentasi $40^{\circ}-42^{\circ} \mathrm{C}$.

Suparthana dkk. (2017), melaporkan bahwa pada sere kedele terdapat sejumlah spesies bakteri, diantaranya dari kelompok Bacillus yakni Bacillus subtilis, B. cereus, $B$. flexus dan B.thuringiensis. Selain bakteri dari kelompok Bacillus ditemukan pula spesies lain yang dikategorikan sebagai bakteri patogen. Diantara spesies bakteri yang ditemukan tersebut belum diketahui dengan pasti, bakteri mana yang berperan penting memfermentasikan kedelai dalam proses pembuatan sere kedele. Berdasarkan pada penelitian yang dilakukan, Bacillus subtilis merupakan salah satu bakteri yang paling sering digunakan dalam produksi kedelai fermentasi karena aman digunakan sebagai bahan tambahan pangan (Hong dkk., 2008) dan memiliki karakteristik proteolitik (Efendi, dkk., 2017), lipolitik (Yuneta dan Putra 2010) dan selulolitik (Bakti, 2012 sedangkan bakteri lainnya seperti B. cereus (Cicilia, 2012) bersifat patogen.

Penggunaan inokulum Bacillus subtilis dalam pembuatan sere kedele disarankan agar diperoleh produk yang konsisten dan terjamin keamanannya sebagai makanan tradisional yang dapat diterima oleh masyarakat. Namun hingga saat ini belum diketahui lama fermentasi yang optimum untuk menghasilkan sere kedele dengan penambahan $B$. subtilis yang memiliki karakteristik yang sama dengan sere kedele yang difermentasi spontan selama 30 jam dengan kondisi suhu ruang. Berdasarkan hal tersebut maka perlu dilakukan penelitian untuk mengetahui lama fermentasi sere kedele dengan bantuan isolat $B$. subtilis.

\section{Tempat dan Waktu}

\section{METODE PENELITIAN}

Penelitian

dilaksanakan

di

Laboratorium Mikrobiologi Pangan, Laboratorium Analisis Pangan, Laboratorium Pengolahan Pangan Fakultas Teknologi Pertanian Universitas Udayana, Laboratorium Rekayasa Proses dan Pengendalian Mutu Fakultas Teknologi Pertanian Universitas Udayana dan UPT Laboratorium Terpadu Biosains dan Bioteknologi Universitas Udayana.. Penelitian dilakukan pada bulan Agustus sampai Oktober 2018.

\section{Bahan dan Alat}

Bahan-bahan yang digunakan dalam penelitian ini terdiri dari bahan baku, bahan tambahan dan bahan kimia. Bahan baku terdiri dari kedelai kuning impor yang diperoleh dari pasar Badung, dan isolat Bacillus subtilis diperoleh dari Laboratorium Mikrobiologi, Fakultas Teknologi Pertanian, Universitas Udayana. Bahan kimia dan bahan lain yang digunakan antara lain : medium Nutrient Broth (Merck), Nutrient Agar (Merck), Pepton Water (PW) 0,1\% , petrifilm ${ }^{\mathrm{TM}}$ AC plate $(3 \mathrm{M})$, akuades, alkohol $96 \%, \mathrm{H}_{2} \mathrm{SO}_{4}$ pekat, larutan lugol, pewarna safranin, kristal violet, phenolpthalein $1 \%$, $\mathrm{NaCl}, \mathrm{NaOH}$, heksan dan tablet Kjeldahl.

Alat yang digunakan dalam penelitian ini adalah laminar air flow cabinet (JSBR 9000 SB), cawan petri, jarum ose, inkubator (Memmert), tabung reaksi, tabung appendorf, mikroskop (Olimpus BX51), rotary shaker (Health HMSR), sentrifuse (K3 Series-BRK), bunsen, waskom, panci, styrofoam, spatula, kompor, timbangan analitik (Shimadsu), 
erlenmeyer, corong, eksikator, batang pengaduk, pipet mikro, labu kjeldal, soxhlet, cawan porselin, penjepit, waterbath (thermology), muffle purnace, gelas ukur dan gelas beker.

\section{Rancangan Percobaan}

Rancangan yang digunakan pada penelitian ini adalah Rancangan Acak Lengkap (RAL) dengan 5 taraf perlakuan berupa lama fermentasi (T). Perlakuan lama fermentasi terdiri dari fermentasi oleh Bacillus subtilis selama 12 jam (T1), 18 jam (T2), 24 jam (T3), 30 jam (T4) dan 36 jam (T5) Seluruh perlakuan diulang sebanyak 3 kali sehingga diperoleh 15 unit percobaan. Data hasil penelitian dianalisis menggunakan sidik ragam pada program SPSS, jika perlakuan berpengaruh terhadap variabel yang diamati, dilanjutkan dengan uji Duncan (Sastrosupadi, 2000).

\section{Pelaksanaan Penelitian}

Proses pelaksanaan penelitian terdiri dari beberapa tahapan yaitu :

\section{Pembuatan kultur kerja}

Isolat B. Subtilis yang diperoleh dari isolasi sere kedele yang telah disimpan dalam kulkas dengan suhu $-70^{\circ} \mathrm{C}$ dijadikan sebagai sumber inokulum. Sebanyak 1 ose dari isolat B.subtilis ditumbuhkan pada media Nutrient Broth (NB) diinkubasi selama 24 jam pada suhu $37{ }^{\circ} \mathrm{C}$. Sebanyak 1 ose dari kultur $B$. subtilis kemudian ditumbuhkan pada media Nutrient Agar (NA) untuk memperoleh koloni tunggal dengan metode strake dan diinkubasi selama 24 jam pada suhu $37{ }^{\circ} \mathrm{C}$. Koloni B.subtilis yang tumbuh pada media nutrient agar sebanyak 1 ose ditumbuhkan ke dalam 5 $\mathrm{mL}$ media nutrient broth (NB) steril dan diinkubasi pada rotary shaker selama 24 jam dengan suhu ruang. Kultur kerja B.subtilis dibuat dengan menanam isolat yang diambil dari media nutrient broth sebanyak 1 ose dan ditanam pada agar miring dengan metode strake.

\section{Uji Konfirmasi}

Uji konfirmasi dilakukan dengan tiga metode yakni pengecatan gram, pengamatan morfologi dan uji katalase.

\section{Penyiapan inokulum Bacillus subtilis}

Sebanyak satu ose isolat Bacillus subtilis diambil dari dari stok kultur kerja dan ditumbuhkan ke dalam $5 \mathrm{ml}$ media NB, dikultur selama 24 jam pada suhu ruang. Jumlah sel B. Subtilis dihitung dengan menggunakan metode sebar. Sebanyak $1 \mathrm{ml}$ kultur dilarutkan dengan pepton water (PW) ditambahkan dalam $9 \mathrm{ml}$ larutan pepton water (pengenceran $10^{-1}$ ) dan dilanjutkan seterusnya sampai pengenceran ke $10^{-7}$. Penghitungan jumlah sel B.subtilis dilakukan pada pengenceran $10^{-6}$ dan $10^{-7}$ yang diambil sebanyak $1 \mathrm{ml}$ dan disebar dalam media NA dan diinkubasi selama 24 jam pada suhu $37^{\circ} \mathrm{C}$. Kemudian dihitung jumlah koloni yang tumbuh.

Inokulum B. Subtilis diperoleh dari 1 $\mathrm{ml}$ kultur B. Subtilis disentrifuse dengan kecepatan 6000 rpm selama 10 menit dengan suhu $4^{\circ} \mathrm{C}$ dan diperoleh pelet pada dasar tabung. Supernatan dibuang dan pelet dicuci menggunakan aquades diulang sebanyak dua kali. Pelet dilarutkan dengan aquades steril sebanyak $5 \mathrm{ml}$, inokulum B.subtilis siap untuk dipakai.

\section{Proses pembuatan sere kedele}

Kedelai dipilih dan dibersihkan dari benda asing kemudian ditimbang sebanyak $100 \mathrm{~g}$, selanjutnya dicuci dengan menggunakan air yang dilakukan sebanyak dua kali pencucian tujuannya untuk menghilangkan semua kotoran yang ada pada kedelai. Kedelai kemudian dimasak sampai kedelai matang pada panci presto bertekanan $80 \mathrm{kPa}$ selama 50 menit dengan perbandingan 1 bagian kedelai : 3 bagian air. Kemudian ditiriskan hingga tidak ada air yang menetes.

Sebanyak 100 gram kedelai masak diinokulasikan dengan starter B.subtilis 
dengan populasi bakteri sebanyak $10^{-7} \mathrm{cfu} / \mathrm{ml}$. Kedelai yang telah tercampur rata dengan kultur bakteri Bacillus subtilis ditempatkan di dalam styrofoam dengan penutup yang telah dilubangi. Kedelai difermentasi pada suhu ruang sesuai dengan perlakuan dengan lama fermentasi 12 jam, 18 jam, 24 jam, 30 jam dan 36 jam. Sebagai kontrol dilakukan fermentasi kedelai secara spontan ditempatkan di dalam besek berukuran $15 \times 15 \mathrm{~cm}$ dan difermentasi pada suhu ruang selama 30 jam (Walianingsih, 2015). Kedelai yang telah difermentasi dicampur dengan bumbu yang sudah dihaluskan dengan komposisi bumbu yang digunakan untuk 100 gram kedelai yaitu 3,6 g gula pasir, 2,8 g bawang merah, $7 \mathrm{~g}$ bawang putih, $0,4 \mathrm{~g}$ cabai, 1,5 g garam, 0,4g ketumbar, 0,4 g merica hitam, 0,4 $\mathrm{g}$ lengkuas, 0,3 $\mathrm{g}$ jahe, $0,8 \mathrm{~g}$ kunyit, $0,4 \mathrm{~g}$ kencur dan $0,8 \mathrm{~g}$ terasi.

Kedelai fermentasi yang telah dicampur bumbu selanjutnya akan dilakukan analisis terhadap variabel yang diamati yaitu kadar air, abu, protein, lemak, karbohidrat, serat kasar, nilai $\mathrm{pH}$, total asam dan total mikorba. Sere kedele mentah dicetak bulat pipih lalu dikeringkan di dalam oven selama \pm 9 jam dengan suhu $32^{\circ} \mathrm{C}$ dan digoreng selama 30 detik pada suhu $180^{\circ} \mathrm{C}$ hingga matang dengan warna kecoklatan (Walianingsih, 2015). Sere kedele yang telah digoreng selanjutnya dilakukan evaluasi sensoris meliputi uji hedonik terhadap warna, aroma, tekstur, rasa dan penerimaan keseluruhan dan uji skoring terhadap rasa.

\section{Variabel yang diamati}

Variabel yang diamati dalam penelitian ini adalah kadar air dengan metode pemanasan (Sudarmadji, dkk., 1997), kadar abu dengan metode pengabuan (Sudarmadji, dkk., 1997), kadar protein dengan metode semi mkro-Kjeldhal (Sudarmadji, dkk., 1997), kadar lemak dengan metode Soxhlet (Sudarmadji, dkk. 1997), kadar karbohidrat dengan metode corboydrate by different
(Winarno, 1991), kadar serat kasar dengan metode hidrolisis asam basa (Sudarmadji, dkk., 1997), nilai $\mathrm{pH}$ menggunakan $\mathrm{pH}$-meter (AOAC, 1995), total asam dengan metode titrasi (Ranggana, 1987) dan total mikroba dengan pengujian Angka Lempeng Total menggunakan Petrifilm Aerobic Count (AC) Plate (Anonim, 2018) terhadap sere kedele mentah dan uji organoleptik pada sere kedele yang telah digoreng (Soekarto, 1985).

\section{HASIL DAN PEMBAHASAN}

Hasil analisis dari sere kedele dengan fermentasi spontan sebagai data primer dan nilai rata-rata kadar air, abu, protein, lemak, karbohidrat, serat kasar, nilai $\mathrm{pH}$ dan total mikroba disajikan pada Tabel 1.

Tabel 1. Nilai rata-rata kadar air, abu, protein, lemak, karbohidrat, serat kasar, nilai $\mathrm{pH}$, total asam dan total mikroba sere kedele fermentasi spontan

\begin{tabular}{lc}
\hline Sere Kedele fermentasi spontan & Jumlah \\
\hline Kadar Air $(\%)$ & $54,91 \pm 0,65$ \\
Kadar Abu (\%) & $2,32 \pm 0,14$ \\
Kadar Protein $(\%)$ & $15,35 \pm 0,53$ \\
Kadar Lemak $(\%)$ & $9,61 \pm 0,32$ \\
Kadar Karbohidrat $(\%)$ & $19,47 \pm 0,92$ \\
Kadar Serat Kasar $(\%)$ & $7,62 \pm 0,30$ \\
Nilai pH & $6,17 \pm 0,06$ \\
Total Asam $(\%)$ & $0,10 \pm 0,01$ \\
Total Mikroba (log cfu/g) & $9,64 \pm 0,03$ \\
\hline
\end{tabular}

Hasil analisis kadar air, abu, protein, lemak, karbohidrat, serat kasar, nilai $\mathrm{pH}$, total asam dan total mikroba dari fermentasi sere kedele oleh $B$. subtilis dengan perlakuan lama fermentasi disajikan pada Tabel 2, Tabel 3 dan Tabel 4.

\section{Kadar Air}

Hasil analisis ragam menunjukkan bahwa lama fermentasi kedelai dengan Bacillus subtilis berpengaruh sangat nyata $(\mathrm{P}<0,01)$ terhadap kadar air sere kedele. Tabel 2 menunjukkan kadar air sere kedele berkisar 
antara $58,05 \%$ sampai $60,77 \%$. Selama proses fermentasi terjadi kenaikan kadar air.

Peningkatan kadar air disebabkan oleh B. subtilis merombak karbohidrat pada kedelai sebagai sumber energi untuk tumbuh dan berkembang. Hasil dari perombakan karbohidrat adalah gula-gula sederhana yang diubah menjadi energi dengan hasil sampingan berupa metabolit, asam, $\mathrm{CO}_{2}$ dan air (Suprihatin, 2010), sehingga semakin lama fermentasi maka kadar air semakin meningkat.

Tabel 2. Nilai rata-rata kadar air, abu dan protein sere kedele.

\begin{tabular}{cccc}
\hline $\begin{array}{c}\text { Lama } \\
\text { Fermentasi }\end{array}$ & $\begin{array}{c}\text { Kadar Air } \\
(\%)\end{array}$ & $\begin{array}{c}\text { Kadar } \\
\text { Abu }(\%)\end{array}$ & $\begin{array}{c}\text { Kadar } \\
\text { Protein } \\
(\%)\end{array}$ \\
\hline 12 jam (T1) & $58,05 \pm$ & $2,39 \pm$ & $15,79 \pm$ \\
& $0,05 \mathrm{~b}$ & $0,07 \mathrm{a}$ & $0,72 \mathrm{a}$ \\
18 jam (T2) & $58,07 \pm$ & $2,24 \pm$ & $15,07 \pm$ \\
& $0,65 \mathrm{~b}$ & $0,11 \mathrm{~b}$ & $0,38 \mathrm{ab}$ \\
24 jam (T3) & $58,39 \pm$ & $2,00 \pm$ & $14,33 \pm$ \\
& $0,41 \mathrm{~b}$ & $0,01 \mathrm{c}$ & $0,32 \mathrm{bc}$ \\
30 jam (T4) & $58,70 \pm$ & $1,95 \pm$ & $13,69 \pm$ \\
& $0,04 \mathrm{~b}$ & $0,03 \mathrm{c}$ & $0,56 \mathrm{c}$ \\
36 jam (T5) & $60,77 \pm$ & $1,90 \pm$ & $12,59 \pm$ \\
& $0,43 \mathrm{a}$ & $0,01 \mathrm{c}$ & $0,34 \mathrm{~d}$ \\
\hline
\end{tabular}

Keterangan: Huruf yang sama dibelakang nilai rata-rata pada kolom yang sama menunjukkan perlakuan berbeda tidak nyata $(\mathrm{P}>0,05)$

Sere kedele yang difermentasi spontan pada penelitian ini memiliki kadar air sebesar $54,91 \%$. Kadar air pada sere kedele fermentasi spontan lebih rendah dari sere kedele fermentasi dengan $B$. subtilis karena wadah yang digunakan berbeda yakni pada sere kedele fermentasi spontan menggunakan besek dan sere kedele fermentasi styrofoam. Air yang dihasilkan selama proses fermentasi pada sere kedele terserap oleh besek (Setyawardhani, 2008) dan penggunaan besek sebagai wadah fermentasi karena besek sebagai sumber mikroba yang berperan dalam fermentasi spontan pada pembuatan sere kedele (Koswara, 1997).

Sere kedele yang beredar di pasar umum Kabupaten Gianyar memiliki kadar air berkisar antara $56,89 \%$ sampai $64,64 \%$ (Widyantari, 2017). Hal ini menunjukkan bahwa kadar air sere kedele yang difermentasi oleh $B$. subtilis berada diantara kadar air sere kedele yang beredar dipasaran.

\section{Kadar Abu}

Hasil analisis ragam menunjukkan bahwa lama fermentasi kedelai dengan Bacillus subtilis berpengaruh sangat nyata $(\mathrm{P}<0,01)$ terhadap kadar abu sere kedele. Tabel 2 menunjukkan kadar abu sere kedele berkisar antara $1,90 \%$ sampai $2,39 \%$. Selama proses fermentasi oleh B.subtilis terjadi penurunan kadar abu.

Abu merupakan zat anorganik sisa hasil pembakaran suatu bahan makanan. Kadar abu menunjukkan total mineral yang terkandung dalam suatu bahan pangan. Hal yang sama dilaporkan Sarkar dkk.(1998), bahwa selama proses fermentasi pada kinema terjadi penurunan sebagian besar mineral yaitu, kalsium, tembaga, besi, mangnesium, mangan dan fosfor. Penurunan kadar abu selama fermentasi disebabkan bakteri menggunakan mineral, vitamin dan gula yang ada pada bahan untuk pertumbuhannya sebagai sumber energi.

Sere kedele yang difermentasi spontan pada penelitian ini memiliki kadar abu sebesar 2,32\%. Kadar abu sere kedele fermentasi spontan berada diantara kadar abu sere kedele yang difermentasi $B$. subtilis dengan lama fermentasi 12 jam hingga 18 jam. Fermentasi sere kedele secara spontan selama 30 jam menghasilkan kadar abu yang lebih tinggi dibandingkan sere kedele yang diperoleh dari fermentasi menggunakan $B$. subtilis dengan waktu yang sama. Hal tersebut disebabkan karena pada sere kedele fermentasi spontan terdapat Klebsiella pneumonia (Suparthana dkk, 2017). Tamang, dkk.(2016) melaporkan bahwa $K$. pneumonia adalah bakteri yang menghasilkan vitamin B12. Vitamin B12 penyusunnya adalah atom cobalt. Atom cobalt akan menjadi residu 
dalam proses pengabuan sehingga terhitung sebagai kadar abu.

Sere kedele yang beredar di pasar umum Kabupaten Gianyar memiliki kadar abu berkisar antara $1,56 \%$ sampai $2,42 \%$ (Widyantari, 2017). Hal ini menunjukkan bahwa kadar abu sere kedele yang difermentasi oleh B. subtilis berada diantara kadar abu sere kedele yang beredar dipasaran.

\section{Kadar Protein}

Hasil analisis ragam menunjukkan bahwa lama fermentasi kedelai dengan Bacillus subtilis berpengaruh sangat nyata $(\mathrm{P}<0,01)$ terhadap kadar protein sere kedele. Tabel 2 menunjukkan kadar protein sere kedele berkisar antara $12,59 \%$ sampai $15,79 \%$. selama proses fermentasi oleh $B$. subtilis terjadi penurunan kadar protein.

Penurunan kadar protein selama proses fermentasi disebabkan karena $B$. subtilis bersifat proteolitik (Efendi dkk., 2017). B. subtilis menghasilkan enzim protease yang mendegradasi protein kedelai selama fermentasi menjadi asam amino, peptida dan amonia ( Chukeatirote, 2015). Selama proses fermentasi oleh $B$. subtilis sejumlah protein digunakan sebagai sumber nitrogen untuk pertumbuhannya, sehingga protein menurun.

Sere kedele yang beredar di pasar umum Kabupaten Gianyar memiliki kadar protein berkisar antara $14,90 \%$ sampai $20,93 \%$ (Widyantari, 2017). Hal ini menunjukkan bahwa kadar protein sere kedele yang difermentasi oleh $B$. subtilis dengan lama fermentasi 12 jam (T1) dan 18 jam (T2) berada diantara kadar protein sere kedele yang beredar dipasaran, sedangkan sere kedele dengan fermentasi $B$. subtilis dengan lama fermentasi 24- 36 jam memiliki kadar protein yang lebih rendah dibandingkan sere kedele dengan fermentasi spontan pada penelitian ini dan yang beredar di pasaran.

Sere kedele difermentasi spontan pada penelitian ini memiliki kadar protein yang lebih tinggi dibandingkan dengan sere kedele yang difermentasi B. subtilis. Hal tersebut disebabkan karena pada sere kedele dengan fermentasi spontan terjadi persaingan antar mikroba menggunakan nutrisi untuk menghasilkan metabolit (Holzaple (2002) dalam Antara ( 2011)). Metabolit yang dihasilkan selama proses fermentasi dapat berupa enzim protease dalam jumlah yang terbatas.Hal ini mengakibatkan hanya sedikit protein yang terdapat pada kedelai menjadi terurai, sehingga kadar protein pada sere kedele fermentasi spontan lebih tinggi dibandingkan dengan sere kedele fermentasi B. subtilis.

Tabel 3. Nilai rata-rata kadar lemak, karbohidrat dan

\begin{tabular}{lccll}
\hline Lama & Kadar & Kadar & Kadar \\
Fermentasi & Kemak (\%) & $\begin{array}{c}\text { Serat } \\
\text { drat(\%) }\end{array}$ & $\begin{array}{c}\text { Kasar } \\
(\%)\end{array}$ \\
\hline 12 jam (T1) & $14,39 \pm$ & $9,38 \pm$ & 8,25 & \pm \\
& $0,26 \mathrm{a}$ & $0,78 \mathrm{~d}$ & $0,13 \mathrm{a}$ & \\
18 jam (T2) & $14,17 \pm$ & $10,65 \pm$ & 8,12 & \pm \\
& $0,52 \mathrm{a}$ & $0,54 \mathrm{c}$ & $0,07 \mathrm{ab}$ & \\
24 jam (T3) & $12,05 \pm$ & $13,24 \pm$ & 7,67 & \pm \\
& $0,47 \mathrm{~b}$ & $0,24 \mathrm{~b}$ & $0,14 \mathrm{bc}$ & \\
30 jam (T4) & $10,66 \pm$ & $15,01 \pm$ & 7,31 & \pm \\
& $0,22 \mathrm{c}$ & $0,32 \mathrm{a}$ & $0,54 \mathrm{~cd}$ & \\
36 jam (T5) & $9,37 \pm$ & $15,37 \pm$ & 6,91 & \pm \\
& $0,15 \mathrm{~d}$ & $0,42 \mathrm{a}$ & $0,29 \mathrm{~d}$ & \\
\hline
\end{tabular}

serat kasar sere kedele.

Keterangan: Huruf yang sama dibelakang nilai rata-rata pada kolom yang sama menunjukkan perlakuan berbeda tidak nyata $(\mathrm{P}>0,05)$.

\section{Kadar Lemak}

Hasil analisis ragam menunjukkan bahwa lama fermentasi kedelai dengan Bacillus subtilis berpengaruh sangat nyata $(\mathrm{P}<0,01)$ terhadap kadar lemak sere kedele. Tabel 3 menunjukkan kadar lemak sere kedele berkisar antara 9,37\% sampai 14,39\%. Selama proses fermentasi terjadi penurunan kadar lemak.

Penurunan kadar lemak selama proses fermentasi disebabkan karena $B$. subtilis bersifat lipolitik yang dapat menghidrolisis lemak. Lipase diproduksi selama fermentasi yang dapat memecah trigliserida menjadi 
asam lemak bebas dan gliserol (Yuneta dan Putra 2010). Asam lemak bebas akan mudah mengalami kerusakan sehingga mengakibatkan kadar lemak menurun selama proses fermentasi (Oktavia dkk., 2012).

Sere kedele dengan fermentasi spontan pada penelitian ini memiliki kadar lemak sebesar $9,61 \%$ yang berada diantara kadar lemak sere kedele yang difermentasi $B$. subtilis dengan lama fermentasi 30 jam (T4) dan 36 jam (T5) dan sere kedele yang beredar dipasar umum Kabupaten Gianyar memiliki kadar lemak berkisar antara 5,34\% sampai 9,50\% (Widyantari, 2017).

\section{Kadar Karbohidrat}

Hasil analisis ragam menunjukkan bahwa lama fermentasi kedelai dengan Bacillus subtilis berpengaruh sangat nyata $(\mathrm{P}<0,01)$ terhadap kadar karbohidrat sere kedele. Tabel 3 menunjukkan kadar karbohidrat sere kedele berkisar antara 9,38\% sampai $15,37 \%$. Selama proses fermentasi terjadi kenaikan kadar karbohidrat.

Kadar karbohidrat sere kedele yang diperoleh berdasarkan by difference pada uji proksimat dipengaruhi oleh nilai dari kadar air, abu, protein dan lemak. Kadar abu, protein lemak sere kedele menurun sehingga kadar karbohirat meningkat. Kadar karbohidrat mengalami kenaikan disebabkan karena selama fermentasi $B$. subtilis menghasilkan eksopolisakarida (Vijayabasskar dkk., 2011), sehingga semakin lama fermentasi maka kadar karbohidrat semakin meningkat.

Sere kedele difermentasi spontan pada penelitian ini memiliki kadar karbohidrat sebesar 19,47\%. Bakteri yang ditemukan pada sere kedele fermentasi spontan yaitu Weissella confuse dan Klebsiella pneumonia (Suparthana dkk.,2017) merupakan jenis yang mampu menghasilkan eksopolisakarida (Malik dkk.,2010 dan Dinoto dkk.,2011). Eksopolisakarida adalah polisakarida yang diekskresikan oleh sel sebagai produk metabolisme berupa homopolisakarida (polimer yang terdiri dari satu macam monosakarida, contohnya dektran dan pullulans) dan heteropolisakarida (polisakarida yang terdiri dari 2-4 macam monosakarida, contohnya eksopolisakarida yang dihasilkan bakteri asam laktat) (Malaka, 2010).

\section{Serat Kasar}

Hasil analisis ragam menunjukkan bahwa lama fermentasi kedelai dengan Bacillus subtilis berpengaruh sangat nyata $(\mathrm{P}<0,01)$ terhadap kadar serat kasar sere kedele. Tabel 3 menunjukkan kadar serat kasar sere kedele berkisar antara 6,91\% sampai 8,25\%. Selama proses fermentasi oleh Bacillus subtilis terjadi penurunan kadar serat kasar.

Penurunan kadar serat kasar selama fermentasi disebabkan karena B.subtilis menghasilkan enzim selulase yang menghidrolisis selulosa menjadi glukosa (Bakti, 2012). Semakin lama fermentasi, maka semakin lama kesempatan $B$. subtilis menghasilkan enzim untuk mendegradasi selulosa pada kedelai, sehingga kadar serat kasar sere kedele semakin menurun. Sere kedele yang difermentasi spontan pada penelitian ini memiliki kadar serat kasar sebesar $7,62 \%$ yang berada diantara kadar serat kasar sere kedele yang difermentasi Bacillus subtilis dengan lama fermentasi 24 jam (T3) dan 30 jam (T4).

\section{Nilai pH}

Hasil analisis ragam menunjukkan bahwa lama fermentasi kedelai dengan $B$. subtilis berpengaruh sangat nyata $(\mathrm{P}<0,01)$ terhadap nilai $\mathrm{pH}$ sere kedele. Tabel 4 menunjukkan nilai $\mathrm{pH}$ sere kedele berkisar antara 5,13 sampai 6,10. Selama proses fermentasi oleh $B$. subtilis terjadi penurunan $\mathrm{pH}$.

Penurunan $\mathrm{pH}$ dikarenakan adanya aktivitas bakteri selama fermentasi yang 
menghasilkan asam-asam organik yang merupakan hasil pemecahan oleh enzim pada fermentasi sere kedele. B. subtilis menghasilkan enzim protease yang mendegradasi protein menjadi asam-asam amino (Efendi dkk., 2017) dan enzim lipase yang mendegradasi lemak menjadi asam lemak (Yuneta, 2010). Semakin lama fermentasi berlangsung maka asam-asam organik yang dihasilkan semakin banyak, sehingga terjadi penurunan nilai $\mathrm{pH}$. Sere kedele yang difermentasi spontan memiliki nilai $\mathrm{pH}$ 6,17 yang memiliki nilai $\mathrm{pH}$ lebih tinggi dibandingkan sere kedele yang difermentasi B. subtilis.

Tabel 4. Nilai rata-rata nilai $\mathrm{pH}$, total asam dan total mikroba sere kedele.

\begin{tabular}{cccc}
\hline $\begin{array}{c}\text { Lama } \\
\text { Fermentasi }\end{array}$ & $\mathrm{pH}$ & $\begin{array}{c}\text { Total Asam } \\
(\%)\end{array}$ & $\begin{array}{c}\text { Total } \\
\text { Mikroba } \\
(\mathrm{log} \\
\mathrm{cfu} / \mathrm{g})\end{array}$ \\
\hline 12 jam (T1) & $6,10 \pm$ & $0,11 \pm$ & $9,59 \pm$ \\
& $0,00 \mathrm{a}$ & $0,01 \mathrm{~d}$ & $0,02 \mathrm{~d}$ \\
18 jam (T2) & $6,03 \pm$ & $0,13 \pm$ & $9,96 \pm$ \\
& $0,06 \mathrm{~b}$ & $0,01 \mathrm{~cd}$ & $0,07 \mathrm{c}$ \\
24 jam (T3) & $6,00 \pm$ & $0,14 \pm$ & $10,33 \pm$ \\
& $0,00 \mathrm{~b}$ & $0,01 \mathrm{bc}$ & $0,03 \mathrm{a}$ \\
30 jam (T4) & $5,70 \pm$ & $0,15 \pm$ & $10,07 \pm$ \\
& $0,00 \mathrm{c}$ & $0,01 \mathrm{ab}$ & $0,03 \mathrm{~b}$ \\
36 jam (T5) & $5,13 \pm$ & $0,16 \pm$ & $9,93 \pm$ \\
& $0,06 \mathrm{~d}$ & $0,01 \mathrm{a}$ & $0,03 \mathrm{c}$ \\
\hline
\end{tabular}

Keterangan: Huruf yang sama dibelakang nilai rata-rata pada kolom yang sama menunjukkan

Total Asam perlakuan berbeda tidak nyata $(\mathrm{P}>0,05)$.

Hasil analisis ragam menunjukkan bahwa lama fermentasi kedelai dengan $B$. subtilis berpengaruh sangat nyata $(\mathrm{P}<0,01)$ terhadap total asam sere kedele. Tabel 4 menunjukkan total asam sere kedele berkisar antara $0,11 \%$ sampai $0,16 \%$.Selama proses fermentasi oleh $B$. subtilis terjadi kenaikan total asam.

Mikroba berperan dalam pembentukan asam-asam organik dan komponen rasa. Asam organik dihasilkan dari proses metabolisme mikroba selama proses fermentasi melalui proses glikolisis. Semakin lama fermentasi, maka mikroba semakin banyak memanfaatkan nutrien dalam kacang kedelai untuk proses metabolisme, sehingga kemampuan mikroba untuk menghasilkan asam-asam organik semakin meningkat (Zaini, 2016). Semakin lama proses fermentasi kedelai oleh B. subtilis maka terjadi kenaikan total asam yang memengaruhi nilai $\mathrm{pH}$ yang semakin menurun. Nilai $\mathrm{pH}$ yang rendah memiliki total asam yang tinggi. Sere kedele yang difermentasi spontan memiliki total asam sebesar $0,10 \%$ yang memiliki nilai lebih rendah dari sere kedele yang difermentasi oleh B.subtilis.

\section{Total Mikroba}

Hasil analisis ragam menunjukkan bahwa lama fermentasi kedelai dengan Bacillus subtilis berpengaruh sangat nyata $(\mathrm{P}<0,01)$ terhadap total mikroba sere kedele. Tabel 4 menunjukkan total mikroba kasar sere kedele berkisar antara 9,59log cfu/g sampai 10,33log cfu/g. Selama fermentasi total mikroba mengalami peningkatan dari awal fermentasi 12 jam $(9,59 \log \mathrm{cfu} / \mathrm{g})$ hingga 24 jam $(10,33 \log \mathrm{cfu} / \mathrm{g})$ dan mengalami penurunan pada lama fermentasi selanjutnya yakni pada jam ke-30 sampai ke-36.

Peningkatan jumlah mikroba dikarenakan mikroba mengalami pertumbuhan berupa pertambahan jumlah sel dengan memanfaatkan nutrisi yang dipecah menjadi gula sederhana yang digunakan sebagai sumber energi. Pada jam ke-30 $(10,07 \log \mathrm{cfu} / \mathrm{g})$ terjadi penurunan total mikroba dimana hal tersebut merupakan fase menuju kematian yang disebabkan oleh nutrien di dalam medium sudah habis dan energi cadangan di dalam sel telah habis (Suprihatin, 2010). Jika dibandingkan dengan fermentasi spontan, nilai rata-rata total mikroba sebesar 9,64 log cfu/g berada diantara total mikroba sere kedele yang difermentasi $B$. subtilis dengan lama fermentasi 12 jam (T1) dan 24 jam (T2). 


\section{Evaluasi Sensoris}

Evaluasi sifat sensori sere kedele dilakukan dengan uji hedonik terhadap warna, tekstur, rasa, aroma dan penerimaan keseluruhan dan uji skoring terhadap rasa. Sere kedele yang disajikan kepada panelis merupakan sere kedele yang telah digoreng. Nilai rata-rata uji hedonik terhadap warna, tekstur, rasa, aroma dan penerimaan keseluruhan dan uji skoring terhadap rasa sere kedele dapat dilihat pada Tabel 5 dan Tabel 6.

Tabel 5. Nilai rata-rata uji hedonik warna, aroma dan tekstur sere kedele.

\begin{tabular}{|c|c|c|c|c|c|c|}
\hline \multirow{2}{*}{$\begin{array}{c}\text { Lama } \\
\text { Fermentasi }\end{array}$} & \multicolumn{6}{|c|}{ Nilai Rata-Rata Uji Hedonik } \\
\hline & \multicolumn{2}{|c|}{ Warna } & \multicolumn{2}{|c|}{ Aroma } & \multicolumn{2}{|c|}{ Tekstur } \\
\hline & 3,67 & \pm & 3,60 & \pm & 3,53 & \pm \\
\hline & $0,49 \mathrm{a}$ & & $0,51 \mathrm{a}$ & & $0,64 \mathrm{a}$ & \\
\hline \multirow[t]{2}{*}{18 jam (T2) } & 3,67 & \pm & 3,67 & \pm & 3,33 & \pm \\
\hline & $0,49 \mathrm{a}$ & & $0,62 \mathrm{a}$ & & $0,62 \mathrm{a}$ & \\
\hline \multirow[t]{2}{*}{24 jam (T3) } & 3,73 & \pm & 3,80 & \pm & 3,53 & \pm \\
\hline & $0,59 \mathrm{a}$ & & $0,56 \mathrm{a}$ & & $0,52 \mathrm{a}$ & \\
\hline \multirow[t]{2}{*}{30 jam (T4) } & 3,60 & \pm & 3,67 & \pm & 3,87 & \pm \\
\hline & $0,50 \mathrm{a}$ & & $0,49 \mathrm{a}$ & & $0,74 \mathrm{a}$ & \\
\hline \multirow[t]{2}{*}{36 jam (T5) } & 3,67 & \pm & 3,40 & \pm & 3,33 & \pm \\
\hline & $0,49 \mathrm{a}$ & & $0,83 \mathrm{a}$ & & $0,72 \mathrm{a}$ & \\
\hline
\end{tabular}

Keterangan: Huruf yang sama dibelakang nilai rata-rata pada kolom yang sama menunjukkan perlakuan berbeda tidak nyata $(\mathrm{P}>0,05)$.

Kriteria hedonik : 1 (sangat tidak suka), 2 (tidak suka), 3 (biasa), 4 (suka), 5 (sangat suka)

\section{Warna}

Hasil sidik ragam menunjukkan bahwa lama fermentasi oleh $B$. subtilis pada sere kedele berpengaruh tidak nyata $(\mathrm{P}>0,05)$ terhadap nilai rata-rata uji hedonik warna dari sere kedele. Tabel 5 menunjukkan bahwa nilai rata-rata uji hedonik warna sere kedele berkisar antara 3,60 (suka) sampai dengan 3,73 (suka).

\section{Aroma}

Hasil sidik ragam menunjukkan bahwa lama fermentasi oleh Bacillus subtilis pada sere kedele berpengaruh tidak nyata $(\mathrm{P}>0,05)$ terhadap nilai rata-rata uji hedonik aroma dari sere kedele. Tabel 5 menunjukkan bahwa nilai rata-rata uji hedonik aroma sere kedele berkisar antara 3,40 (biasa) sampai 3,80 (suka).

\section{Tekstur}

Hasil sidik ragam menunjukkan bahwa lama fermentasi oleh $B$. subtilis pada sere kedele berpengaruh tidak nyata $(\mathrm{P}>0,05)$ terhadap nilai rata-rata uji hedonik tekstur dari sere kedele. Tabel 5 menunjukkan bahwa nilai rata-rata uji hedonik tekstur sere kedele berkisar antara 3,33 (biasa) sampai 3,87 (suka).

Tabel 6. Nilai rata-rata uji hedonik rasa dan penerimaan keseluruhan dan uji skoring rasa sere kedele

\begin{tabular}{|c|c|c|c|}
\hline \multirow{2}{*}{$\begin{array}{c}\text { Lama } \\
\text { Fermentasi }\end{array}$} & \multicolumn{2}{|c|}{ Rasa } & \multirow{2}{*}{$\begin{array}{l}\text { Uji Hedonik } \\
\text { Penerimaan } \\
\text { Keseluruhan }\end{array}$} \\
\hline & $\begin{array}{c}\text { Uji } \\
\text { Hedonik }\end{array}$ & $\begin{array}{c}\text { Uji } \\
\text { Skoring }\end{array}$ & \\
\hline 12 jam & $\begin{array}{l}3,40 \pm \\
0,83 \mathrm{a}\end{array}$ & $\begin{array}{l}3,60 \pm \\
0,50 \mathrm{~b}\end{array}$ & $3,53 \pm 0,83 b$ \\
\hline 18 jam (T2) & $\begin{array}{l}3,33 \pm \\
0,49 \mathrm{a}\end{array}$ & $\begin{array}{l}3,47 \pm \\
0,64 b\end{array}$ & $3,40 \pm 0,63 b$ \\
\hline $24 \operatorname{jam}(\mathrm{T} 3)$ & $\begin{array}{l}3,80 \pm \\
0,56 \mathrm{a}\end{array}$ & $\begin{array}{l}3,33 \pm \\
0,62 b\end{array}$ & $4,07 \pm 0,46 \mathrm{a}$ \\
\hline $30 \mathrm{jam}$ & $\begin{array}{l}3,53 \pm \\
0,52 \mathrm{a}\end{array}$ & $\begin{array}{l}3,20 \pm \\
0,41 \mathrm{~b}\end{array}$ & $3,53 \pm 0,53 b$ \\
\hline 36 jam (T5) & $\begin{array}{l}2,73 \pm \\
0,88 \mathrm{~b}\end{array}$ & $\begin{array}{l}4,20 \pm \\
0,68 \mathrm{a}\end{array}$ & $2,80 \pm 0,86 \mathrm{c}$ \\
\hline
\end{tabular}

Keterangan: Huruf yang sama dibelakang nilai rata-rata pada kolom yang sama menunjukkan perlakuan berbeda tidak nyata $(\mathrm{P}>0,05)$.

Kriteria hedonik : 1 (sangat tidak suka), 2 (tidak suka), 3 (biasa), 4 (suka), 5 (sangat suka)

Kriteria skoring : 1 (sangat tidak asam), 2 (tidak asam), 3 (agak asam), 4 (asam), 5 (sangat asam)

\section{Rasa}

Hasil sidik ragam menunjukkan bahwa lama fermentasi oleh fermentasi $B$. subtilis pada sere kedele berpengaruh sangat nyata $(\mathrm{P}<0,01)$ terhadap nilai rata-rata uji hedonik dan uji skoring rasa sere kedele. Tabel 6 menunjukkan bahwa nilai rata-rata tertinggi diperoleh pada lama fermentasi 24 jam (T3) yaitu sebesar 3,80 (suka) serta tidak berbeda dengan lama fermentasi 12 jam (T1), 18 jam (T2) dan 30 jam (T4), sedangkan nilai ratarata terendah diperoleh pada lama fermentasi 
36 jam (T5) yaitu sebesar 2,73 (biasa). Tingkat kesukaan panelis terhadap rasa sere kedele dipengaruhi oleh lama fermentasi kedelai oleh $B$. subtilis dimana semakin lama fermentasi maka sere kedele memiliki rasa asam. Tingkat kesukaan panelis tertinggi diperoleh pada lama fermentasi 24 jam yang memiliki rasa agak asam.

Nilai rata-rata uji skor rasa sere kedele pada Tabel 6 menunjukkan bahwa nilai ratarata terendah diperoleh pada lama fermentasi 30 jam (T4) sebesar 3,20 (agak asam) serta berbeda tidak nyata dengan perlakuan lama fermentasi 24 jam (T3) sebesar 3,33 (agak asam), 18 jam (T2) sebesar 3,47 (agak asam) dan 12 jam (T1) sebesar 3,60 (asam) dan nilai rata-rata tertinggi diperoleh pada lama fermentasi 36 jam (T5) sebesar 4,20 (asam). Berdasarkan penilaian panelis sere kedele yang semakin asam kurang disukai.

Semakin lama fermentasi maka rasa sere kedele akan semakin asam. Selama fermentasi asam-asam organik dihasilkan dari proses metabolisme mikroba melalui proses glikolisis dan adanya aktifitas $B$. subtilis yang menghasilkan enzim protease ( Chukeatirote, 2015) dan lipase (Yuneta, 2010) yang mampu mengubah substrat menjadi asamasam amino dan asam lemak.

\section{Penerimaan Keseluruhan}

Hasil sidik ragam menunjukkan bahwa lama fermentasi oleh Bacillus subtilis pada sere kedele berpengaruh sangat nyata $(\mathrm{P}<0,01)$ terhadap nilai rata-rata uji hedonik penerimaan keseluruhan sere kedele. Tabel 6 menunjukkan bahwa nilai rata-rata tertinggi diperoleh pada lama fermentasi 24 jam (T3) yaitu sebesar 4,07 (suka), sedangkan nilai rata-rata terendah diperoleh pada lama fermentasi 36 jam (T5) yaitu sebesar 2,80 (biasa). Nilai rata-rata uji hedonik penerimaan keseluruhan baik dari segi warna, tekstur, rasa dan aroma menunjukkan bahwa sere kedele dengan fermentasi oleh $B$. subtilis dapat diterima oleh panelis.

\section{KESIMPULAN DAN SARAN \\ Kesimpulan}

Berdasarkan hasil penelitian yang telah dilakukan dapat diambil kesimpulan sebagai berikut :

1. Lama fermentasi oleh $B$. berpengaruh sangat nyata terhadap kadar air, abu, protein, lemak, karbohidrat, serat kasar, nilai $\mathrm{pH}$, total asam, total mikroba, uji skor dan hedonik rasa dan uji hedonik penerimaan keseluruhan sere kedele dan berpengaruh tidak nyata terhadap uji hedonik warna, aroma dan tekstur.

2. Lama fermentasi 12 jam oleh Bacillus subtilis menghasilkan karakteristik terbaik pada pembuatan sere kedele dengan kriteria kadar air 58,05\%, kadar abu 2,39\%, kadar protein 15,79\%, kadar lemak $14,39 \%$, kadar karbohidrat 9,38\%, kadar serat kasar $8,25 \%$, nilai $\mathrm{pH} 6,1$, total asam $0,11 \%$, total mikroba $9,59 \log \mathrm{cfu} / \mathrm{g}$, warna, aroma, tekstur disukai, rasa biasa dengan rasa asam serta penerimaan keseluruhan disukai.

\section{Saran}

Berdasarkan penelitian diatas disarankan untuk melakukan penelitian lebih lanjut mengenai :

1. Pengaruh penggunaan isolat bakteri tunggal atau campuran yang terdapat pada sere kedele untuk menghasilkan sere kedele yang dapat diterima oleh masyarakat.

2. Pengaruh penggunaan suhu fermentasi dalam proses pembuatan sere kedele sehingga menghasilkan sere kedele yang dapat diterima oleh masyarakat.

\section{DAFTAR PUSTAKA}

Anonimous.1995.Method of Analysis. Association of Official Analytical Chemistry. Washington D.C 
Anonimous.2018. 3M Petrifilm Aerobic Count Plates. https://www.3m.com/3M/en_US/compa ny-us/all-3m-products/ /AEROBIC-

3M-Petrifilm-Aerobic-CountPlates/?N=5002385+3293785706\&rt=r ud [Diakses Online tanggal 20 Agustus 2018].

Antara, N. S. 2011. Peran Bakteri Asam Laktat Strain Lokal untuk Memperbaiki Mutu dan Keamanan Produk Pangan Lokal. Orasi Ilmiah. Tidak Dipublikasikan. Fakultas Teknologi Pertanian. Universitas Udayana.

Bakti, C.P.2012. Optimasi Produksi Enzim Selulase dari Bacillus sp. BPPT CC RK2 dengan Variasi $\mathrm{pH}$ dan Suhu Menggunakan Response Surface Methodology.Skripsi.

Tidak Dipublikasikan. Fakultas Teknik. Universitas Indonesia

Chukeatirote, E. 2015. Thua nao : Thai fermented soybean. J.Ethn Foods 2:115118.

Cicilia, A.P. 2012. Ketahanan Spora dan Sel Vegetatif Bacillus cereus Terhadap Suhu Awal Preparasi dan Selama Penyimpanan Makanan Pendamping Asi Bubuk Instan. Skripsi. Tidak Dipublikasikan. Sekolah Pascasarjana. Institut Pertanian Bogor. Chukeatirote, E. 2015. Thua nao : Thai fermented soybean. J.Ethn Foods 2:115-118.

Dinoto,A., Saputra, S., Nugroho, A.J. dan Rahayu, R.D. 2011. Keanekaragaman bakteri penghasil eksopolisakarida asal saluran cerna manusia. Berk.Penel.

Efendi,Y., Yusra dan V. Efendi. 2017. Optimasi potensi bakteri Bacillus subtilis sebagai sumber enzim protease. Jurnal Akuatika Indonesia 2(1): 87-94.
Koswara, S. 1997. Mengenal makanan tradisional. Bagian 1: Hasil olahan kedelai. Buletin Teknologi \& Industri Pangan 8(2): 74-78.

Malaka, R. 2010. Eksopolisakarida bakteri starter kultur susu fermentasi sebagai sumber polisakarida harapan di masa depan. Orasi Ilmiah. Tidak Dipublikasi. Fakultas Peternakan. Universitas Hasanuddin.

Malik, A., A.K. Hermawati, M. Hestiningtyas, A. Soemiati dan M. Radji. Isolasi dan skrining molekuler bakteri asam laktat pembawa gen glukansukrase dari makanan dan minuman mengandung gula. Makara, Sains. 14(1):63-68.

Oktavia, A.D., D. Mangunwidjaja dan S. Wibowo. 2012. Pengelolahan limbah cair perikanan menggunakan konsorsium mikroba indigenous proteolitik dan lipolitik. Jurnal Agorintek. 6(2):65-71.

Ranggana, S. 1987. Manual Analysis of Fruit and Vegetable Product. Mc Graw Publishing Company Limited. New Delhi.

Sarkar,P., E. Morisson, U.Tinggi, S.M. Somerset dan G.S. Craven. 1998. BGroup vitamin and mineral contents of soybeans during kinema production. J. Sci. Food.Agric. 78: 498-502.

Sastrosupadi, A., 2000. Rancangan Percobaan Praktis Bidang Pertanian. Penerbit Kanisus, Yogyakarta.

Soekarto, S.T. 1985. Penilaian Organoleptik untuk Industri Pangan dan Hasil Industri Pertanian. Bharata, Jakarta. 
Setyawardhani, R.D. 2008. Pengaruh Jenis Kemasan dan Volume Ketan Terhadap Fermentasi Serta Perubahan Mutu Tape Ketan Hitam Selama Penyimpanan. Skripsi. Tidak dipublikasikan. Fakultas Teknologi Pertanian. Institut Pertanian Bogor.

Sudarmadji, S., Haryono, B., Suhardi. 1997. Analisa Bahan Makanan dan Pertanian. Liberty Yogyakarta, Yogyakarta.

Suparthana, I P, A.S. Duniaji, dan H. Masayuki. 2017. Investigation and molecular analysis of balinese traditionally produced soybean fermented food, sere kedele. Prosiding Seminar Nasional Sains dan Teknologi (Senastek) IV, Bali, Indonesia.

Suprihatin. 2010. Teknologi Fermentasi. UNESA University Press, Surabaya.

Tamang, J.P., D.H. Shin, S.J. Jung dan S.W. Chae. 2016. Functional Properties of Microorganism in Fermented Foods. Frontiers in Microbiology, 7.

Tamang,J.P. 2015. Naturally fermented ethnic soybean foods of india. Journal of Ethnic Foods 2: 8-17

Vijayabaskar, P., Babinastarlin, S., Shankar, T., Sivakumar, T. Dan Anandapandian, K.T.K. 2011. Quantification and characterization of exopolysaccharides from Bacillus subtilis (MTCC 121). Advances in Biological Research 5(2): $71-76$
Walianingsih, E.J. 2015. Pengaruh Lama Fermentasi Kedelai Terhadap Karakteristik Sere Kedele. Skripsi. Tidak dipublikasikan. Fakultasi Teknologi Pertanian. Universitas Udayana.

Wei, Q., W.Hall, K.C.Chang. 2001. Natto characteristics as affected by steaming time, bacillus strain, and fermentation time. Journal Food Microbiology and Safety 66(1): 167-173.

Widyantari, M.D. 2017. Inventarisasi dan Kajian Mutu Sere Kedele di Pasar Umum Kabupaten Gianyar. Skripsi. Tidak dipublikasikan. Fakultas Teknologi Pertanian. Universitas Udayana.

Winarno, F.G. 1991. Kimia Pangan dan Gizi. Gramedia Pustaka Utama, Jakarta.

Yuneta, R. dan S.R. Putra. 2010. Pengaruh Suhu pada Lipase dari Bakteri Bacillus subtilis. Prosiding Kimia FMIPA. Tidak Dipublikasikan. Institut Teknologi Sepuluh November. Surabaya.

Zaini, Z.O.F. Pengaruh Lama Fermentasi Terhadap Nilai pH, Total Asam, Jumlah Mikroba, Protein dan Kadar Alkohol Kefir Susu Kacang Kedelai. Skripsi. Tidak dipublikasikan.Universitas Islam Negeri Maulana Malik Ibrahim Malan 